\title{
Small Groups in a Social Learning MOOC (sIMOOC): Strategies for Fostering Learning and Knowledge Creation
}

\author{
Marianne E. Krasny \\ Cornell University \\ Bryce DuBois \\ Rhode Island School of Design \\ Mechthild Adameit \\ Independent Consultant, Uruguay \\ Ronnie Atiogbe \\ University of Lomé, Togo
}

Muhammad Lukman Baihaqi Alfakihuddin

Indonesian Biodiversity and Conservation

Tergel Bold-erdene

Ulaanbaatar Broadcasting System, Mongolia

Zahra Golshani

University at Albany

Rodrigo González-González

National Autonomous University of Mexico

Ishmael Kimirei

Tanzania Fisheries Research Institute

Yamme Leung

World Wide Fund for Nature, Hong Kong

Lo Shian-Yun

National Taiwan Normal University

Yue Yao

World Animal Protection, Beijing 


\begin{abstract}
Social support and face-to-face learning may enhance outcomes for students who face barriers in accessing Massive Open Online Courses (MOOCs). This study investigated how self-identified volunteer leaders guide and foster interactions among small groups of students who face technical and conceptual barriers in accessing MOOC content. Several months prior to the start of the MOOC (Environmental Education: Transdisciplinary Approaches to Addressing Wicked Problems), registered students volunteered to lead small groups for participants whose primary language was other than English and where limited Internet access and cultural barriers curtailed access to and understanding of course materials and pedagogy. Results of a survey and in-depth interviews $(N=10)$ revealed that group leaders were instrumental in overcoming barriers related to language, content, cultural ways of learning, access, and time. Group leaders also fostered cooperative learning strategies, which helped students acquire course content, and encouraged collaborative group projects leading to groups adopting some features of online knowledge communities. The term social learning MOOC (sIMOOC) is proposed to capture a growing trend of incorporating collaborative learning strategies in XMOOCs and to emphasize how MOOCs use interactive learning strategies to help students apply course content to local contexts and thus may contribute localized knowledge to globalized MOOC learning environments.
\end{abstract}

Keywords: Small groups, MOOCs, social learning, knowledge creation, hybrid learning

Krasny, M.E., DuBois, B., Adameit, M., Atiogbe, R., Alfakihuddin, M.L.B., Bold-erdene, T., ... Yao, Y. (2018). Small groups in a social learning MOOC (slMOOC): Strategies for fostering learning and knowledge creation. Online Learning, 22(2), 119-139.

doi:10.24059/olj.v22i2.1339

\title{
Small Groups in a Social Learning MOOC (sIMOOC): Strategies for Fostering Learning and Knowledge Creation
}

Multiple challenges threaten our ability to realize the MOOC vision of establishing "education as a fundamental human right, where anyone around the world with the ability and the motivation could get the skills that they need to make a better life for themselves, their families and their communities" (Koller, 2012). Students from developing and other countries may be hampered by limited English language proficiency, "content overload," feeling as if they don't belong and there is no sense of community, experiencing threats to social identity in a large anonymous course with many better prepared participants, and even lack of familiarity with computers and insufficient access to reliable electricity. Further the materials may lack local relevance and thus be in need of "cultural translation" (Bartholet, 2013; de Waard et al., 2014; Godwin-Jones, 2014; Jung \& Gunawardena, 2014; Kizilcec, Saltarelli, Reich, \& Cohen, 2017; Liyanagunawardena \& Adams, 2014; Meinel \& Schweiger, 2016; Nkuyubwatsi, 2014; Yuan \& Kim, 2014). These barriers likely contribute to the predominance of well-educated professionals from more developed countries in MOOCs, with less than 3\% of MOOC students from least developed countries (Laurillard, 2016). 
One strategy to address these barriers is forming small groups of students who interact online, meet in person, or use a combination of online and in-person social networking and learning strategies. Such groups often focus on project-based learning (N. Li et al., 2014; Nkuyubwatsi, 2014) or simply understanding the course content. They can be formed as local "MeetUps" (Glader, 2012) or embassy-sponsored "MOOC camps" (Godwin-Jones, 2014), and facilitated by skilled educators (Chen \& Chen, 2015), graduate students (Gunawardena and Jayatilleke, 2014), nonprofit organizations (Bartholet, 2013), and volunteers recruited and trained by MOOC instructors (Colas, Sloep, \& Garreta-Domingo, 2016). For students whose first language is not English, group leaders can help translate course materials, facilitate course discussions in students' native language, and help students apply the materials to their own cultural context (Colas et al., 2016; Nkuyubwatsi, 2014). Factors influencing the ability of online language-based peer groups to foster student success include group size and preexisting sense of community engendered by the strength of cultural identity (Colas et al., 2016).

To the extent that small groups promote discussion and sharing among students, they may not only address cultural barriers but also be considered a form of social learning (Bandura, 1977; Wals, 2007). Other strategies to promote social learning and sense of community in MOOCs include discussion forums and social media, such as Facebook groups (Kellogg, Booth, \& Oliver, 2014; Laurillard, 2016) and short activities to make students feel part of the course community (Kizilcec et al., 2017). Social network analysis (Kellogg et al., 2014) and content analysis of student posts (Y. Li et al., 2014) in online course discussion forums and Facebook groups suggest that students form connections with each other and that the instructor plays a role in facilitating these student-student connections.

Recognizing that online courses can create learning communities similar to those found in face-to-face courses, Garrison, Anderson, and Archer (2003) proposed the Community of Inquiry framework as a tool to understand not only content acquisition but also social interactions. Researchers applying this framework use discussion board posts and other student text to determine the extent of cognitive and social "presences" and the degree and quality of instructor "presence" during an online course. Social presence and peer-to-peer interaction in MOOCs can promote learning though sharing among students and through learners contributing to the collective knowledge (Margaryan, Bianco, \& Littlejohn, 2015). Focusing more broadly on online communities in which participants learn and co-create knowledge (e.g., Wikipedia, citizen science, cMOOCs), Jeong, Cress, Moskaliuk, and Kimmerle (2017) proposed four increasingly intense levels of interactions varying in the degree to which community members share common goals, processes, and outcomes: attendance, coordination, cooperation, and collaboration (A3C). Although the $\mathrm{A} 3 \mathrm{C}$ knowledge community framework was developed in the context of large, open online communities, the authors suggest that it could have value for smaller and face-to-face groups (Jeong et al., 2017). Importantly, interactions among students may not only help address cultural barriers and enhance learning but also have the potential to add "local" knowledge to MOOCs, which otherwise may exclude non-Western forms of knowledge. In fact, the large scale of MOOCs can enable interactions and the co-creation of knowledge among diverse learners globally (Stewart, 2013).

In this in-depth study, we apply social learning and knowledge community frameworks to understand participant interactions and outcomes in self-organized, local, and language-based "community groups" formed by MOOC student volunteer leaders in non-English-speaking and developing countries. More specifically, we ask three questions: (1) what are the leaders' goals for 
themselves and their community groups? (2) what barriers do MOOC students face and what activities do leaders facilitate to address barriers? and (3) what types of interactions and knowledge co-creation take place in small groups? In the interest of recognizing their contributions to and reflections about their community groups, group leaders are included with course instructors as co-authors on this paper. We hope that our combined perspectives will be useful to MOOC designers seeking to address barriers to accessing MOOC content and pedagogy and will further our understanding of knowledge community practices in MOOCs.

The MOOC that is the subject of this inquiry included lectures and readings consistent with xMOOCs but did not include true/false or multiple-choice questions. Instead our assignments consisted of open-ended discussion questions and a final project, and we facilitated an active Facebook group to afford opportunities for students to connect with others with similar interests, share resources, and think more deeply about course concepts. Reflecting the significant number of xMOOCs that incorporate students learning from each other (Margaryan et al., 2015) but do not approach the more radical self-directed pedagogy of cMOOCs, we propose the term social learning $M O O C$ or $s l M O O C$ to capture this pedagogical approach.

\section{Review of Related Literature}

Although the term massive in MOOCs conjures up images of untold numbers of students being subject to "mass" education from elite professors, Stewart (2013) argues that the massive numbers of students create possibilities for MOOCs to become a "Trojan horse" upsetting traditional knowledge acquisition pedagogy. Even in xMOOCs where interaction is limited to discussion boards, students are afforded opportunities to network with other students and to share knowledge. Stewart (2013) claims that the larger the number of students the more opportunities for knowledge co-creation that subverts the expert-driven model of xMOOCs.

Many online course instructors encourage networking and knowledge sharing and even knowledge co-creation through social media (e.g., Facebook, WeChat), discussion boards, and small groups (Colas et al., 2016; de la Varre, Keane, \& Irvin, 2011; Kellogg et al., 2014; Nkuyubwatsi, 2014). Anders (2015) attempts to capture the ways in which MOOCs afford such networking opportunities in a kind of "hybrid" between cMOOCs, in which learners take the responsibility for self-organizing an open, collaborative learning experience, and xMOOCs, in which experts provide lectures and readings for students to absorb. In integrating aspects of network-based cMOOCs and content-based xMOOCs, hybrid MOOCs draw from sociocultural and cognitive behaviorist pedagogies, attempting to create a sense of community while guiding task-based activities (Anders, 2015). Because the term hybrid has also been used for MOOCs that blend in-person and online learning, the term social learning MOOC may be a less confusing term for referring to MOOCs that integrate sociocultural and cognitive behaviorist pedagogies.

\section{Social Learning in MOOCS}

We propose the term social learning MOOC (slMOOC) to focus on the purpose and unique features of MOOCs that integrate peer-to-peer interactions with content provision. Although social learning has a long history with multiple and sometimes confusing definitions (Reed et al., 2010), we draw from the work of sustainability and learning scholar Arjen Wals (2007) in defining the characteristics of social learning. In particular, Wals and colleagues (2009) have identified five elements of social learning that are relevant in addressing wicked issues of sustainability. The first 
three elements are the following: We learn from each other, we learn more in groups of people who don't all think alike, and trust and social cohesion are essential building blocks in the process of learning from people who hold different views. MOOC instructional design principles reflect these principles; for example, "learning is promoted when learners collaborate with each other" and "contribute to the collective knowledge" (Margaryan et al., 2015), and learning "enables dialogue," "fosters collaboration," and "creates a community of peers" (Conole, 2015). Research applying these MOOC design principles has demonstrated that small groups whose participants are more diverse lead to better learning outcomes (Kulkarni, Cambre, Kotturi, Bernstein, \& Klemmer, 2015). Further, Kizilcec et al. (2017) claim that the social identity threat experienced by developing country professionals with poorer educational backgrounds becomes a barrier to learning in MOOCs that can be addressed by simple interventions that foster inclusiveness and equity, thus paving the way for trust and social cohesion in impersonal and sometimes daunting MOOCs.

Wals et al.'s (2009) last two principles reflect a more in-depth process of interaction leading to knowledge co-creation and even action. They state that social learning is a process of collectively coming to understand a situation, and social learners help create the learning process and the solutions to the dilemmas they face and, thus, are more likely than passive learners to follow up with action. Project-based learning, which is common in MOOCs and often takes place in smaller study groups (N. Li et al., 2014, Gunawardena \& Jayatilleke, 2014 ), offers the possibility for learners to develop a collective understanding that could lead to action.

\section{Social Interactions in Online Knowledge Communities}

Garrison, Anderson, and Archer (1999) developed the Community of Inquiry model for designing and understanding online course activity, which is composed of three "presences": cognitive, social, and teaching. Here we focus on social presence, which includes open and critical discussion of online material as mediated by group cohesion, open communication, and affective expression. These interactions serve multiple purposes, including supporting cognitive learning (Garrison, Anderson, \& Archer, 2010), creating a feeling of being part of a community of learners and developing an identity as a learner in a massive online course (Kizilcec et al., 2017; Macià \& García, 2016), and providing opportunities to exchange ideas and co-construct knowledge and even new practices that can be used by other educators (Macià \& Garcia, 2017; Macià \& García, 2016). Instructors can enhance social interactions through choice of online platform-for example, discussion board versus social media (Clarke \& Kinne, 2012; Hou, Wang, Lin, \& Chang, 2015; Salmon, Ross, Pechenkina, \& Chase, 2015) - and type of discussion question posed (Ke, 2010), as well as by incorporating structured collaborative activities and assessments of collaboration (Collazos, Gonzalez, \& Garcia, 2014) and focusing on life experience or case-study analysis (Liu \& Yang, 2014).

Jeong et al. (2017) developed a framework for interactions more broadly in online knowledge communities focused on learning and knowledge co-construction, including Wikipedia, citizen science projects, and cMOOCs. As xMOOCs incorporate social learning and knowledge co-construction and, thus, become slMOOCs, such a framework may be helpful in understanding types of interactions and in designing courses consistent with social learning pedagogy.

According to Jeong et al. (2017), four types of interactive processes varying along a continuum between individual and collective responsibility are found in online knowledge 
communities. At one end of the spectrum of interaction is attendance, in which members are driven by individualistic goals, act as individuals, and seek personal benefits. MOOC participants who "freeload," or act as lurkers, exemplify this process. A somewhat stronger form of interaction is coordination, in which participants maintain their individualistic goals, but reaching their goals is dependent on the contributions of fellow community members. Moving away from individualistic interaction is cooperation, in which members share goals and participate in joint activities but still work independently much of the time. Finally, collaboration involves shared goals, processes, and outcomes (Jeong et al., 2017). In addition to the degree of shared goals, processes, and outcomes, important factors in distinguishing online communities include the use of artifacts, such as the online platform and community norms, to mediate interactions and their potential to support coconstruction of knowledge. Whereas Garrison et al.'s (2010) social presence is useful in describing what types of interactions occur on course discussion boards and other platforms, Jeong et al.'s (2017) framework invites us to look more closely at individual participant and group goals and outcomes as well as the interactive processes through which these outcomes are achieved in small groups and larger online communities.

\section{Cultural Influences in Online Learning}

Cultural differences between and within societies strongly influence the ways online learners access and process course materials and participate in course discussions. Cultural factors taken into account in online learning environments include language, ways of perceiving visual images, power differentials between instructors and students, collectivist versus individualistic norms, educational background, and familiarity, use, and access to computers (Jung \& Gunawardena, 2014; Liyanagunawardena \& Adams, 2014). A key challenge for MOOCs is how to address issues related to the hegemony of Western ways of learning (Jung \& Gunawardena, 2014) and Western knowledge and its governance within globally diverse cultures (cf. Hulme, 2010), as well as social identity threat (Kizilcec et al., 2017) and feelings of isolation, sociocultural inferiority or misfit, and lack of necessary technical skills-referred to as psychological, sociocultural, and technical distance, respectively (Gunawardena, 2014b).

Focusing on feelings of being less capable among students from developing countries, MOOC instructors used an intervention in which learners were asked to affirm their values related to reasons for taking the course, which increased MOOC completion rates for students from lesser developed countries while decreasing retention for students from more developed countries (Kizilcec et al., 2017). Other interventions have focused more specifically on helping students understand and apply course materials to their local setting. These "social learning" interventions include self-organized small groups of learners taking the course together (Nkuyubwatsi, 2014); collecting and sharing student narratives (Krasny \& Snyder, 2016) or video-based projects (Godwin-Jones, 2014) that apply course content to local contexts; discussions, and resource sharing over social media; discussions over live webinars including chats; and graduate student ementors who collaborate with small groups of students on an inquiry-based learning project (Jung \& Gunawardena, 2014). Such approaches are generally preferred to MOOC-platform discussion boards, which generally are not user-friendly for online learners accustomed to social media. Further, students from non-Western cultures may feel uncomfortable challenging the instructor's and fellow learners' ideas in the formal learning context (Gunawardena \& Jayatilleke, 2014). These interactive forms of learning also facilitate participants constructing their own learning subcultures (Jung, 2014) and identities, through processes such as building trust, self-disclosure, and negotiating miscommunications (Gunawardena, 2014a). 
In short, multiple strategies have been used to foster social learning in MOOCs, with the goal of addressing cultural barriers and thus fostering learning among students, particularly those from non-Western cultures. Although less researched, social learners in MOOCs also have the potential to create new knowledge, similar to that produced by other collaborative online knowledge communities. slMOOCs might address issues related to Western knowledge hegemony by creating a more localized learning environment for MOOC participants and by contributing locally specific knowledge to the more globalized knowledge of MOOC learning environments.

\section{Methods}

\section{MOOC Description}

This research focuses on the Environmental Education: Transdisciplinary Approaches to Addressing Wicked Problems MOOC offered by Cornell University in spring 2016. The goal of the course was to create an environmental education "trading zone" (Galison, 1999), or an online space where instructors, university students, and professionals learn about research from multiple disciplines, that sheds light on how to change environmental behaviors and improve environmental quality. In addition to 65 lectures drawing on multiple disciplines, the course promoted trading zones through the discussion board; discussions and sharing resources and practices on course Facebook, WeChat, Telegram, and KakaoTalk social media groups; and the course project, which involved creating a case study applying the course content to a local environmental education program. Students who completed weekly assignments were awarded an achievement certificate, while those who also completed the course project earned an expert certificate.

Prior to the start of the course, we invited registered students to create and take leadership for community groups, including local groups whose leaders were expected to organize weekly in-person meetings to discuss the course materials, bilingual groups whose leaders helped members understand the materials during in-person meetings and using online communications, and interest groups whose leaders facilitated web-mediated discussions of a particular topic. Seventy-two participants were accepted as community group leaders, 42 of whom led groups throughout the course (Table 1). We provided ongoing web-mediated training and support for the community leaders.

Of the 3,306 individuals who registered for the course, 2,294 students from 140 countries entered the course site, 2,355 joined the course Facebook group, and 1,257 completed one assignment. Of students who registered for course, $15.4 \%$ earned the achievement certificate and $8.2 \%$ earned the expert certificate. Of the 304 students who joined community groups, 29.3\% earned an achievement and $36.5 \%$ an expert certificate. 
Table 1.

Complete List of Community Group Types, Participant Numbers, and Names

\begin{tabular}{|c|c|c|c|}
\hline $\begin{array}{l}\text { Group } \\
\text { Type }\end{array}$ & $\begin{array}{l}\text { Groups } \\
(n)\end{array}$ & $\begin{array}{l}\text { Participants } \\
(n)\end{array}$ & Names \\
\hline Local & 19 & 187 & $\begin{array}{l}\text { Beijing; Chile; Dallas Zoo; Dubai; Eau Claire, WI; Attica, Greece; Hong } \\
\text { Kong; Kigoma, Tanzania; Kingston, Jamaica; Toliara, Madagascar; } \\
\text { Mexico City, Mexico; Montevideo, Uruguay; Prescott, AZ; Roaring Fork } \\
\text { Valley, CO; Taipei, Taiwan; Tehran, Iran; Lomé, Togo; Ulaanbaatar, } \\
\text { Mongolia; Xalapa, Mexico }\end{array}$ \\
\hline Interest & 13 & 110 & $\begin{array}{l}\text { Caribbean; Climate Change Mitigation and Adaptation; Climatic Change } \\
\text { Biodiversity/Habitat Loss; Conservation Education; Curricular Integration } \\
\& \text { Applications for Educators; EARTHCARE and Environmental } \\
\text { Education; Ecopsychology; Food Security and Environment in Nigeria; } \\
\text { Zoos; Application of Global Online Course in Professional and Academic } \\
\text { Settings; Informal Education in a Park Setting; Monarch Habitat } \\
\text { Restoration Conservation; Urban Environmental Education }\end{array}$ \\
\hline Bilingual & 9 & 58 & $\begin{array}{l}\text { Farsi; Francophone; German; Indonesian; Mandarin (2); Spanish (2), } \\
\text { Lusophone }\end{array}$ \\
\hline Total & 41 & 304 & \\
\hline
\end{tabular}

This is a qualitative case study of small groups in the Environmental Education: Transdisciplinary Approaches to Addressing Wicked Problems MOOC. We administered postcourse surveys and conducted follow-up interviews with 10 group leaders. The 10 community leaders included in this study of the larger sample of 42 leaders were chosen because they led groups whose primary language was not English and where limited Internet access and cultural and other barriers curtailed access to and understanding of course materials and pedagogy.

\section{Data Collection}

A survey and follow-up interviews were used to learn about motivations and outcomes for group leaders as a result of leading a group, barriers experienced and efforts to address barriers, and group process (e.g., recruitment, meeting frequency). The survey and follow-up interviews included discrete and open-ended questions about group leader motivations and professional outcomes; type of social media used to connect group members; learning barriers for group participants (language, access, content, other, no barriers); number of meetings and average number of group members attending; strategies used to facilitate group discussion about the course material, guide participants in course assignments, and support group member social, personal, or professional development; and challenges faced in organizing and running groups.

\section{Data Analysis}

Interviews were transcribed verbatim and used along with the survey questions to compile case summaries for each group. We coded themes in interview transcripts and open-ended survey questions related to barriers, professional development outcomes, and motivations for leading a group. The second author used an open-coding strategy in which he wrote memos regarding themes as they emerged from the texts and organized them into categories that represented overlapping themes, using an iterative process until saturation was reached among themes (Saldaña, 2013). To address validity, we used member checking, asking the group leader 
interviewees to review, edit, and revise the initial case studies. To address validity and ethical issues, the interviewees reviewed drafts and were invited to join us as co-authors on this paper. The group leaders/co-authors clarified details about the cases, including group relationships before, during, and after the course, efforts to overcome barriers, and group activities after the course ended. The first and second authors (who were course instructor and group leader coordinator) deferred to the group leaders where discrepancies emerged. The quotations were chosen for clarity and depth, resulting in perspectives from group leaders who were more fluent in English or more active being better represented. Thus, the results suggest what is possible under favorable conditions for small groups.

\section{Results}

The community groups that are the focus of this study were from China, Tanzania, Indonesia, Togo, Mexico, Uruguay, Taiwan, Iran, and Mongolia (Table 2). Group leaders worked in nonprofits and were graduate students, research directors, journalists, and environmental educators. They recruited group members by talking with colleagues, employing word of mouth, and using social media. They held anywhere from one meeting during the course to several meetings a week, and they used informal interactions at work and closed social media groups on Facebook, WeChat (China), and Telegram (Iran).

Table 2.

Survey/Interview Group Leader and Group Descriptive Information

\begin{tabular}{|c|c|c|c|c|c|c|}
\hline Group name & $\begin{array}{l}\text { Demographics } \\
\text { (gender, age, } \\
\text { education) }\end{array}$ & Leader & Recruitment & Members & Meetings & Facilitation \\
\hline $\begin{array}{l}\text { Beijing, } \\
\text { China }\end{array}$ & $\begin{array}{l}\text { Female, 34, MSc } \\
\text { (Environmental } \\
\text { Management) }\end{array}$ & $\begin{array}{l}\text { Project } \\
\text { communication } \\
\text { officer for World } \\
\text { Wildlife Fund } \\
\text { (WWF) }\end{array}$ & $\begin{array}{l}\text { Through previous } \\
\text { workplace (Jane } \\
\text { Goodall Institute) }\end{array}$ & $\begin{array}{l}\text { Environmental } \\
\text { educator } \\
\text { colleagues at Jane } \\
\text { Goodall Institute }\end{array}$ & $\begin{array}{l}\text { Informal } \\
\text { interactions } \\
\text { at work }\end{array}$ & WeChat \\
\hline $\begin{array}{l}\text { Hong Kong, } \\
\text { China }\end{array}$ & $\begin{array}{l}\text { Male, 38, MSc } \\
\text { (Environmental } \\
\text { Management) }\end{array}$ & $\begin{array}{l}\text { Conservation and } \\
\text { environmental } \\
\text { educator with } \\
\text { WWF }\end{array}$ & $\begin{array}{l}\text { Talking with } \\
\text { colleagues and } \\
\text { course Facebook } \\
\text { group }\end{array}$ & $\begin{array}{l}\text { Environmental } \\
\text { educator } \\
\text { colleagues at } \\
\text { WWF and } \\
\text { university students } \\
\text { and environmental } \\
\text { educators recruited }\end{array}$ & $\begin{array}{l}\text { Informal } \\
\text { interactions } \\
\text { at work }\end{array}$ & $\begin{array}{l}\text { Facebook to plan } \\
\text { meetings }\end{array}$ \\
\hline $\begin{array}{l}\text { Kigoma, } \\
\text { Tanzania }\end{array}$ & $\begin{array}{l}\text { Male, 45, PhD } \\
\text { (Ecology) }\end{array}$ & $\begin{array}{l}\text { Director and } \\
\text { researcher, } \\
\text { Tanzania Fisheries } \\
\text { Research Institute }\end{array}$ & Word of mouth & $\begin{array}{l}\text { Fellow scientists at } \\
\text { fisheries research } \\
\text { institute }\end{array}$ & $\begin{array}{l}\text { Once/week, } \\
\text { but interest } \\
\text { waned after } 2 \\
\text { weeks } \\
\end{array}$ & Facebook group \\
\hline $\begin{array}{l}\text { Kuta, } \\
\text { Badung Bali, } \\
\text { Indonesia }\end{array}$ & Male & $\begin{array}{l}\text { Researcher at } \\
\text { Indonesian } \\
\text { Biodiversity and } \\
\text { Conservation, } \\
\text { university lecturer, } \\
\text { NGO, Mojokerto, } \\
\text { East Java }\end{array}$ & Word of mouth & $\begin{array}{l}\text { High school and } \\
\text { college students, } \\
\text { farmers with little } \\
\text { formal education }\end{array}$ & $\begin{array}{l}\text { Twice/week } \\
\text { in members' } \\
\text { homes }\end{array}$ & Facebook group \\
\hline Lomé, Togo & Male, 27, BA & $\begin{array}{l}\text { Graduate student at } \\
\text { the University of } \\
\text { Lomé }\end{array}$ & Word of mouth & Graduate students & Once/week & Facebook group \\
\hline $\begin{array}{l}\text { Mexico City, } \\
\text { Mexico }\end{array}$ & $\begin{array}{l}\text { Male, 36, MA } \\
\text { student } \\
\text { (Sustainability } \\
\text { Science) }\end{array}$ & $\begin{array}{l}\text { Graduate student at } \\
\text { National } \\
\text { Autonomous } \\
\text { University of } \\
\text { Mexico and } \\
\text { ecological reserve } \\
\text { employee }\end{array}$ & $\begin{array}{l}\text { Word of mouth, } \\
\text { posting } \\
\text { information on } \\
\text { university and } \\
\text { other Facebook } \\
\text { groups }\end{array}$ & $\begin{array}{l}\text { University students } \\
\text { or recent graduates } \\
\text { who had taken } \\
\text { leader's seminar on } \\
\text { social-ecological } \\
\text { issues }\end{array}$ & Once/week & $\begin{array}{l}\text { Facebook group to } \\
\text { post resources } \\
\text { (inactive during } \\
\text { course), WhatsApp } \\
\text { to organize } \\
\text { meetings }\end{array}$ \\
\hline
\end{tabular}




\begin{tabular}{|c|c|c|c|c|c|c|}
\hline \multicolumn{7}{|c|}{ Survey/Interview Group Leader and Group Descriptive Information } \\
\hline $\begin{array}{l}\text { Montevideo, } \\
\text { Uruguay }\end{array}$ & $\begin{array}{l}\text { Female, 39, MA } \\
\text { (Economics) }\end{array}$ & $\begin{array}{l}\text { Intercultural } \\
\text { Consultant, Coach, } \\
\text { and Facilitator, } \\
\text { Rocha, Uruguay }\end{array}$ & $\begin{array}{l}\text { Posting } \\
\text { information on } \\
\text { Facebook, emails } \\
\text { to environmental } \\
\text { associations and } \\
\text { news lists }\end{array}$ & $\begin{array}{l}\text { College students to } \\
\text { retirees, some } \\
\text { having met through } \\
\text { the Uruguayan } \\
\text { Environmental } \\
\text { Education Network }\end{array}$ & 25 total & $\begin{array}{l}\text { Facebook to } \\
\text { discuss topics, } \\
\text { WhatsApp to } \\
\text { organize meetings }\end{array}$ \\
\hline $\begin{array}{l}\text { Taipei, } \\
\text { Taiwan }\end{array}$ & $\begin{array}{l}\text { Female, 36, MA } \\
\text { student } \\
\text { (Environmental } \\
\text { Education) }\end{array}$ & $\begin{array}{l}\text { Graduate student, } \\
\text { National Taiwan } \\
\text { Normal University }\end{array}$ & $\begin{array}{l}\text { Her professor } \\
\text { announced to } \\
\text { students and } \\
\text { other professors }\end{array}$ & $\begin{array}{l}\text { Graduate students } \\
\text { and a professor }\end{array}$ & Once/week & $\begin{array}{l}\text { Facebook for } \\
\text { announcement and } \\
\text { to connect course } \\
\text { discussion to news }\end{array}$ \\
\hline Tehran, Iran & Female, PhD & $\begin{array}{l}\text { Iranian-American } \\
\text { postdoctoral fellow }\end{array}$ & $\begin{array}{l}\text { Telegram (social } \\
\text { media) personal } \\
\text { contacts with } \\
\text { NGOs and } \\
\text { MOOC } \\
\text { registrants }\end{array}$ & $\begin{array}{l}\text { University students } \\
\text { and NGO } \\
\text { employees }\end{array}$ & $\begin{array}{l}2-3 \\
\text { times/week, } \\
3-5 \text { hours } \\
\text { each }\end{array}$ & $\begin{array}{l}\text { Telegram group to } \\
\text { support } \\
\text { communication } \\
\text { and discussion, } \\
\text { and to post } \\
\text { materials }\end{array}$ \\
\hline $\begin{array}{l}\text { Ulaanbaatar, } \\
\text { Mongolia }\end{array}$ & $\begin{array}{l}\text { Female, 24, MA } \\
\text { candidate } \\
\text { (International } \\
\text { Relations) }\end{array}$ & $\begin{array}{l}\text { Student and } \\
\text { journalist for } \\
\text { Ulaanbaatar } \\
\text { Broadcasting } \\
\text { Services and } T V \\
\text { Zone magazine } \\
\end{array}$ & $\begin{array}{l}\text { Through existing } \\
\text { Facebook group }\end{array}$ & $\begin{array}{l}\text { Students or part- } \\
\text { time workers }\end{array}$ & $\begin{array}{l}\text { Once, then } \\
\text { through } \\
\text { Facebook }\end{array}$ & $\begin{array}{l}\text { Facebook to } \\
\text { stimulate } \\
\text { discussion }\end{array}$ \\
\hline
\end{tabular}

The groups had from 1 to 20 regularly attending and 6 to 35 total participants, 12 of whom earned achievement and 45 of whom earned expert certificates (Table 3). The total sample of 79 group participants represented $24 \%$ of participants who completed at least one assignment, $25 \%$ of students who earned achievement certificates, and 59\% of students who earned expert certificates (Table 3 ).

\section{Table 3.}

Survey/Interview Community Group Numbers and Completion Rates

\begin{tabular}{|c|c|c|c|c|c|c|}
\hline \multirow[t]{2}{*}{ Group name } & \multirow{2}{*}{$\begin{array}{c}\text { Number of } \\
\text { meetings }\end{array}$} & \multicolumn{2}{|c|}{ Participants } & \multicolumn{3}{|c|}{ Certificates by group } \\
\hline & & $\begin{array}{r}\text { Regularly } \\
\text { attending }\end{array}$ & $\begin{array}{r}\text { Total } \\
\text { members* }\end{array}$ & Achievement & Expert & $\begin{array}{r}\text { Total } \\
(\%) \\
\end{array}$ \\
\hline Beijing, China & 5 & 5 & 15 & 5 & 0 & $5(33)$ \\
\hline Hong Kong, China & 5 & $5-7$ & 15 & 1 & 3 & $4(27)$ \\
\hline Kigoma, Tanzania & 3 & 1 & 10 & 0 & 0 & $0(0)$ \\
\hline $\begin{array}{l}\text { Kuta, Badung Bali, } \\
\text { Indonesia }\end{array}$ & 11 & 9 & 15 & 0 & 1 & $1(7)$ \\
\hline Lomé, Togo & 9 & 15 & 15 & 0 & 0 & $0(0)$ \\
\hline Mexico City, Mexico & 17 & 5 & 7 & 1 & 6 & $7(100)$ \\
\hline Montevideo, Uruguay & 25 & 7 & 8-9 & 0 & 7 & $7(78)$ \\
\hline Taipei, Taiwan & 15 & 5 & 6 & 4 & 0 & $4(67)$ \\
\hline Tehran, Iran & 12 & $15-20$ & 35 & 0 & 28 & $28(80)$ \\
\hline Ulaanbaatar, Mongolia & 4 & 5 & 13 & 1 & 0 & $1(8)$ \\
\hline $\begin{array}{l}\text { Total community } \\
\text { group members } \\
\text { earning certificates }\end{array}$ & & & 140 & $\begin{array}{c}12 \\
(9 \%)\end{array}$ & $\begin{array}{c}45 \\
(32 \%)\end{array}$ & $\begin{array}{r}57 \\
(42 \%)\end{array}$ \\
\hline $\begin{array}{l}\text { Total regularly } \\
\text { attending group } \\
\text { members earning } \\
\text { certificates }\end{array}$ & & & & $(15 \%)$ & $(57 \%)$ & $(72 \%)$ \\
\hline
\end{tabular}

\footnotetext{
* Includes participants who did not attend all sessions
} 


\section{Group Leader Motivations and Benefits}

Group leaders described altruistic motives for leading a group, including those related to helping fellow students, helping their community, and helping the environment (8 of 10 leaders, Table 4). Interestingly, this motivation reflects the course instructors' motives, which are to teach courses that go beyond helping individuals advance their careers to encompass making a difference in the local community and environment. Four leaders spoke about professional development motivations, including increasing knowledge of online teaching as a potential career and learning more about the environment.

Prominent among the leaders' professional development outcomes was networking or expanding existing networks (4 of 10 leaders). Also important were professional opportunities beyond the course, including receiving an internship, enhancing community engagement around stewardship projects, additional lecturing responsibilities, organizational skills applied to participants' NGO, confidence to apply to a U.S. graduate degree program, and further opportunities to collaborate with U.S. colleagues in teaching online courses. Other outcomes included acquiring pedagogical skills, learning about environmental education, and learning about country needs related to online learning.

\section{Table 4.}

Group Leader Outcomes and Motivations, Responses to Open-Ended Questions

\begin{tabular}{|c|c|}
\hline \multicolumn{2}{|r|}{ Themes across group leaders (\# of leaders) } \\
\hline Motivations & $\begin{array}{l}\text { - Help environmental educators/NGO/community/environment (4) } \\
\text { - Help other students (4) } \\
\text { - } \text { Take on additional responsibilities (1) } \\
\text { - } \text { Motivate young people to take action (1) } \\
\text { - } \text { Love of teaching (1) } \\
\text { - } \text { Meet people from different cultures through group leader trainings (1) } \\
\text { - } \text { Career/professional development (4) }\end{array}$ \\
\hline Outcomes & $\begin{array}{l}\text { - } \\
\text { - } \\
\text { Petwork (4) } \\
\text { - } \quad \text { Pedagosional development beyond course, such as leadership in NGO and } \\
\text { management (3) } \\
\text { - Learned content (2) } \\
\text { - Confidence/empowerment leading to opportunities beyond course (2) } \\
\text { - } \quad \text { Learned about country's environmental education needs (1) } \\
\text { - }\end{array}$ \\
\hline
\end{tabular}

\section{Social Learning and Interactions to Address Barriers to MOOC Learning}

Barriers to learning included time, language, access to technology, cultural differences in pedagogy, and difficulty of content (Table 5). Group leaders and participants translated course materials, and participants took turns presenting the readings at meetings so that not every student had to read all materials. They commonly downloaded or printed materials to help participants 
with limited Internet access; in one case (Togo), slow Internet speed prevented the group leader from accessing the prerecorded lectures, so the group focused only on readings. For the Beijing and Tehran groups, the Canvas platform was blocked, requiring workarounds (e.g., instructors sending the course content on a hard drive). Leaders summarized and simplified content and shared real-world, local examples to address cultural barriers, including participants not being familiar with open-ended discussion questions and personal reflection, and content not relating to students' past experiences or local context. In the three groups whose members did not know each other beforehand (Iran, Uruguay, and Mongolia), leaders spent time helping participants get to know one another, which they deemed necessary for participants to engage fully in the course.

\section{Table 5.}

\section{Barriers and Group Leader Strategies to Address Barriers}

\begin{tabular}{|c|c|c|}
\hline Barrier type & Description & Strategies used to address \\
\hline Time & Limited time given content complexity & Divided up course readings among participants \\
\hline Language & Limited English proficiency & $\begin{array}{l}\text { Translated material or divided up translation } \\
\text { responsibilities among group. }\end{array}$ \\
\hline Access & $\begin{array}{l}\text { Inability or difficulty accessing Canvas } \\
\text { and Facebook platforms, lack of access to } \\
\text { computers, slow Internet }\end{array}$ & $\begin{array}{l}\text { Moved course content to a different platform } \\
\text { accessible to group, received hard drive with } \\
\text { course material from course leaders, downloaded } \\
\text { videos, printed readings and discussion board } \\
\text { questions }\end{array}$ \\
\hline Cultural & $\begin{array}{l}\text { Unfamiliar pedagogical approach, course } \\
\text { design, or course content based on } \\
\text { unfamiliar culturally specific examples }\end{array}$ & $\begin{array}{l}\text { Provided culturally relevant examples. Discussed } \\
\text { main course concepts at length }\end{array}$ \\
\hline )ifficulty & $\begin{array}{l}\text { Difficulty understanding course content } \\
\text { due to lack of familiarity with topic or } \\
\text { educational background }\end{array}$ & $\begin{array}{l}\text { Provided synopses of the readings and lectures } \\
\text { along with additional examples, asked participants } \\
\text { that understood material to share. Attempted to } \\
\text { simplify and narrow concepts and disciplines } \\
\text { discussed }\end{array}$ \\
\hline
\end{tabular}

Below we use quotes from community leader interviews to describe social learning and interaction processes in more depth. We draw heavily from more active groups; thus, our intent is to shed light on the possibilities for social learning and interaction rather than to make a statement about the "average" group.

A common strategy for learning in groups was what we refer to as divide and conquer. Leaders divided up responsibility for learning the content by assigning individual group participants to review and share lectures and readings at group meetings. Shian from Taiwan describes this strategy:

Every week one person led the discussion about one topic. We watched the lecture together. The leader shared the reading and what they learned about the topic and led a discussion. Everyone didn't read everything. Anyone interested took on a topic. People just chose what they liked and led for that topic. 
Mechthild, the community leader in Uruguay, describes the process as follows:

I took a topic, asked someone to do a small presentation, asking what has been a problem, terms, or something that has not been well understood, or something that they wanted to talk about ... that seemed very interesting.

Yamme describes a similar process for the Hong Kong group:

Students relied on the community group to learn. It became a channel to learn from each other. Students were busy and so did not have enough time to access the materials. They learned the course material indirectly.

That this process benefitted from leaders getting to know students and group facilitation skills is evident in Mechthild's statement:

When asking for contributions from the group, I knew what I could ask from someone and what I could not. So when distributing tasks that was not always, let's say, the most democratic way. I asked, always, if they wanted to do something, but if there was no volunteer I would suggest the person that I would think would most easily be able to do the task.

Shian goes further to explain how she tried to connect the content with students' individual experiences:

I encouraged people in the group to share and connect their experience with the content. Some things were new and I tried to connect them with personal experience. This helped people to understand what they were learning. Everyone shared their opinion and experience with the topic. We watched the lecture together and the topic leader would start the conversation, talk about the reading and then discuss connections with the content. Then we worked together on the discussion board. Although we entered our answers separately we collectively prepared for the discussion.

The group learning also benefitted from the different interests and expertise of course participants. As Mechthild describes,

We had different interests. We had some that were more interested in geography, some more interested in social sciences. And so we divided. We said ok, someone is doing a summary on that topic, another person on another. And so that helped as well because you could have someone say, "while I was trying to do the summary I saw this video, and it is fantastic! You have to watch it." And then you get more ideas.

This divide-and-conquer strategy meant that group members became dependent on each other for learning and provided an impetus for them to work together. As Mechthild commented,

The group really became such a team, like it was very hard for someone to get all the questions and to get all the points to pass.

Much group learning was focused on simply getting through the course content, leaving little time for discussion. Zahra (Iran) described how most of her group meetings focused on translating and understanding the class content with only 1 or 2 sessions having sufficient time for discussions. For Zahra's group, this inability to engage in deeper discussions was due not just to the content 
being challenging for Farsi speakers but also to the unfamiliar pedagogy. At first Zahra did not understand why her group members were not answering the discussion questions but then realized they weren't comfortable and were not grasping the questions. The challenge was that the discussion questions did not directly reflect the content but required students to make connections between the content and personal experience. To address this challenge, Zahra developed a second Telegram group she called "discussion question nights," in which she helped students to translate and understand the questions.

Some groups went beyond divide and conquer to engage in what more closely resembled collaboratively trying to understand a concept like wicked problems or even creating new knowledge. Rodrigo González-González's Mexican university group rarely split up readings but spent significant time discussing readings, issues, members' perspectives, and possibilities, methods, and results related to their course project (local case study).

The course project offered additional opportunities for collaboration, as Mechthild relates:

All had an interest in going for the expert certificate, so rather early I started to ask what would be a topic they would like and whether they would do it individually or as a group and so... after 3 or 4 meetings we already started to think what would be the case study.

Although community group participants lived nearby and spoke a common language, some groups included both university students and faculty alongside NGO and government professionals. This diversity was challenging for the group in Iran, which was not used to learning in such "mixed" settings. Despite this challenge, the groups in Iran and Uruguay formed tight social connections through communal meals during meetings and helping each other get through the course. As Mechthild explains,

There was a lot of sharing. ... We had one case where one person was really behind. And I remember the last hours before the deadline that she needed to have all of these done, there was all of these people supporting her to be able to pass, so that we could go on as a group to do the expert certificate.

In the Iranian and Uruguayan groups, this bonding extended beyond the course content, as when Iranian students supported a colleague who had a family emergency and Uruguayan students supported peers who were trying to become licensed horticulturalists. Similarly, the Mexican community group leader continues to work with several group members beyond the course.

It is important to couch these findings from active community groups in the context of community groups that were less active, in large part due to issues related to slow Internet and accessibility. For example, in Ishmael's group of coworkers in Tanzania, few students engaged with the course materials, and the main communication was informal conversation in the workplace. And in Togo, most students - including the community group leader-were not able to access the course lectures due to slow Internet. In Mongolia, students' unfamiliarity with environmental education led to lower levels of group activity. Finally, it is important to point out that community leaders put not only significant time but also their own resources into the course; Zahra delayed returning to the United States so that she could work with the group in Tehran, and Lukman (Indonesia) copied the course materials for his students so they would not have to pay for access in Internet cafés. 


\section{Discussion}

This in-depth study of small group interactions in a MOOC reveals barriers to universal access related to slow Internet (Togo, Tanzania, Indonesia), blocked access to course platform and social media groups (Iran, China), and unfamiliar Western-based course content and interactive pedagogies. In addition, this study sheds light on the altruistic and professional development motives and benefits that led MOOC participants to volunteer to lead small groups, which are consistent with the instructors' motives for teaching an environmental education online course. Below we focus on how these self-identified group leaders addressed understanding and pedagogical barriers by fostering aspects of social learning and cooperation and collaboration. We discuss types of interactions related to sharing knowledge and course projects in the community groups and place the groups and larger MOOC within the context of online knowledge communities where small groups, discussion boards, and other course sociotechnical artifacts afford different types of interactions, learning, and co-creation of knowledge (cf. Jeong et al., 2017).

Whereas social learning is often conceived as creating knowledge to address wicked sustainability issues for which there is no right answer (Krasny \& Dillon, 2013; Wals, 2007), in the MOOC community groups in this study, social learning centered primarily around the course content and secondarily around co-construction of knowledge. Students learned from each other in groups of diverse professionals consistent with social learning tenets (Wals et al., 2007), which resulted in them depending on fellow group members to understand the content and earn a certificate. The groups' divide-and-conquer strategy emphasized helping each other get through the course content and become comfortable with the course pedagogy, whose weekly assignments were exclusively open-ended discussion questions rather than more familiar "right answer" questions. Dividing tasks is also a common pedagogical strategy used by classroom instructors in assigning work to groups, which similar to our community groups exhibit limited capacity to create new knowledge (Zhang, Scardamalia, Reeve, \& Messina, 2009) compared to Wikipedia, citizen science, and other online knowledge communities specifically designed to co-create knowledge (Jeong et al., 2017). That said, the community group interactions in this study did incorporate features of knowledge communities, including cooperation, characterized by shared goals of learning course content but distributed action related to individual students taking responsibility for specific lectures and readings (Jeong et al., 2017).

In the Iran group and several other groups, interactions expanded to encompass collaboration (Jeong et al., 2017) as students jointly undertook local course projects, which provided greater opportunity for social learning to create new knowledge and action. Small project-based groups are a common form of interaction in online university courses (N. Li et al., 2014) and increasingly in MOOCs (Grünewald et al., 2013; Gunawardena \& Jayatilleke, 2014). When focused on applying course content to local contexts (Gunawardena \& Jayatilleke, 2014; Nkuyubwatsi, 2014), these projects can foster social learning and address critiques related to "diminishing, or even erasing, of a geographical sensibility in the making, mobilising and consumption of knowledge about global environmental change" (Hulme, 2010, p. 559). Collaborative course projects in this study provided opportunities to come to a common understanding around an issue and foster collaborative action, as when the Iranian students went on a field trip to a small village and gained an understanding of the role of traditional doll making in ecotourism and developed a joint ecotourism case study for their course project. To encourage collaboration and knowledge co-creation, instructors can incorporate specific design elements into 
online courses. For example, instructors can assemble local course projects into eBooks that become sharable knowledge or artifacts for future knowledge communities (Civic Ecology Lab, 2017; Krasny \& Snyder, 2016; Russ, 2015, Y. Li, 2016).

The community groups in this study may also have changed over time, as has been seen when students move from individually to collectively oriented goals, assume joint responsibility, and form a group identity (Jeong et al., 2017; Tajfel \& Turner, 1986). Although we did not trace change in leader or member goals or identity during this study, in postcourse interviews leaders talked about a mix of professional development and more altruistic goals, some of which may have changed as they interacted with students. In the Uruguay and Iran groups, participants supported each other as they pursued professional goals outside the group (e.g., professional licensing) or experienced a family emergency. It is possible that as group members met over the course of the MOOC and assumed important roles (e.g., summarizing lectures), they also developed a group identity and felt more welcome and efficacious in the large online course (cf. Kizilcec et al., 2017).

Members of small groups may form professional networks that join together and continue after the course, thus spurring knowledge co-construction (Zhang et al., 2009) and formation of larger online knowledge communities, such as those described by Jeong et al. (2017). During one of our lab's subsequent online courses (Urban Environmental Education), the Beijing group in this study spawned a new community group, which conducted multiple "extra-MOOC" activities during the course and has now expanded to an active online (WeChat-mediated) community of over 1,200 members. As members share resources, pose questions, and find out about and take advantage of additional face-to-face and online learning opportunities, they are becoming not only a knowledge community but also a support network for an emerging cadre of environmental educators in China.

\section{Conclusion}

The importance of participant interaction to promote learning and, to a lesser extent, knowledge co-creation is not only foundational to cMOOCs but also recognized by a significant proportion of xMOOCs. In a study of 76 MOOCs, Margaryan et al. (2015) found that nearly half of xMOOCs and nearly all cMOOCs required participants to learn from each other, whereas $10 \%$ of $\mathrm{xMOOCs}$ and $42 \%$ of cMOOCs required learners to contribute to the collective knowledge. Conole (2015) developed a system for classifying MOOCs along 12 dimensions, two of which emphasized participant interaction (extent of student collaboration and student communication through discussions and blogs). As xMOOCs come to incorporate more social learning elements, including social media and collaborative projects, they increasingly resemble online knowledge communities and take on features of social learning or slMOOCs. Related to our course, analyzing our students' definitions of wicked problems, environmental education, and other terms that do not readily transcend language and culture submitted to the discussion board might provide new perspectives on the use of these terms in diverse global contexts and artifacts to be used in future courses, consistent with the work of knowledge communities that incorporate local knowledge.

In short, self-identified small groups in MOOCs can be used to address access issues, promote social learning, and potentially generate new knowledge used in future courses. In this study, small groups used divide-and-conquer strategies, group discussions, and collaborative projects to learn the course content and apply it to local contexts. Moving closer to becoming 
knowledge communities, some small groups demonstrated additional types of activities and interactions, such as the Iran group where students supported a member experiencing a personal difficulty, ate meals together, conducted a field trip, and helped students grapple with questions, such as how they would be viewed by the other MOOC students, how a group composed not just of students but also professionals could come together in a course, and suspicion about why a U.S. university would provide a free course for students in Iran. In a subsequent sIMOOC with significant numbers of Chinese students, community groups met not only to discuss course content but also invited outside speakers, helped each other develop work-related projects, and created active WeChat networks across groups to discuss applications of the course content. Thus, small groups not only help students succeed in MOOCs but also may extend the impact of MOOCs as knowledge communities beyond the period of active instruction and beyond the goals initially defined by instructors. 


\section{References}

Akyol, Z., Garrison, D. R., \& Ozden, M. Y. (2009). Online and blended communities of inquiry: exploring the developmental and perceptional differences. The International Review of Research in Open and Distributed Learning, 10(6).

Anders, A. (2015). Theories and applications of Massive Online Open Courses (MOOCs): The case for hybrid design. International Review of Research in Open and Distance Learning, 16(6), 1-13. doi:10.19173/irrodl.v16i6.2185

Bandura, A. (1977). Social learning theory. Englewood Hills, NJ: Prentice-Hall, Inc.

Bartholet, J. (2013). Free online courses bring "magic" to Rwanda. Scientific American. Retrieved from https://www.scientificamerican.com/article/free-online-classes-bringmagic-rwanda/

Chen, Y.-H., \& Chen, P.-J. (2015). MOOC study group: Facilitation strategies, influential factors, and student perceived gains. Computers \& Education, 86, 55-70. doi:http://dx.doi.org/10.1016/j.compedu.2015.03.008

Civic Ecology Lab. (2017). 25 lesson plans for urban environmental educators. Ithaca NY: Cornell University Civic Ecology Lab.

Clarke, L. W., \& Kinne, L. (2012). More than words: Investigating the format of asynchronous discussions as threaded discussions or blogs. Journal of Digital Learning in Teacher Education, 29(1), 4-13.

Colas, J.-F., Sloep, P. B., \& Garreta-Domingo, M. (2016). The effect of multilingual facilitation on active participation in MOOCs. The International Review of Research in Open and Distributed Learning, 17(4).

Collazos, C. A., Gonzalez, C. S., \& Garcia, R. (2014). Computer supported collaborative MOOCs: CSCM. Paper presented at the Proceedings of the 2014 Workshop on Interaction Design in Educational Environments, Albacete, Spain.

Conole, G. (2015). MOOCs as disruptive technologies: Strategies for enhancing the learner experience and quality of MOOC. Revista de Educación a Distancia, 1(39), 17 (online only). Retrieved from http://revistas.um.es/red/article/view/234221

de la Varre, C., Keane, J., \& Irvin, M. J. (2011). Dual perspectives on the contribution of on-site facilitators to teaching presence in a blended learning environment. Journal of Distance Education, 25(3), 1-14.

de Waard, I., Gallagher, M. S., Zelezny-Green, R., Czerniewicz, L., Downes, S., KukulskaHulme, A., \& Willems, J. (2014). Challenges for conceptualising EU MOOC for vulnerable learner groups. Paper presented at the Proceedings of the European MOOC Stakeholder Summit 2014.

Galison, P. (1999). Trading zone: Coordinating action and belief. In M. Biagioli (Ed.), The science studies reader (pp. 137-160). New York, NY: Routledge.

Garrison, D. R., Anderson, T., \& Archer, W. (1999). Critical inquiry in a text-based environment: Computer conferencing in higher education. The Internet and Higher Education, 2(2), 87-105. doi:http://dx.doi.org/10.1016/S1096-7516(00)00016-6 
Garrison, D. R., Anderson, T., \& Archer, W. (2003). A theory of critical inquiry in online distance education. In M. G. Moore \& W. G. Anderson (Eds.), Handbook of distance education. Mahwah, NJ: Erlbaum Associates.

Garrison, D. R., Anderson, T., \& Archer, W. (2010). The first decade of the community of inquiry framework: A retrospective. The Internet and Higher Education, 13(1), 5-9. doi:http://dx.doi.org/10.1016/j.iheduc.2009.10.003

Glader, P. (2012). MOOC meetup groups point to a blended (online + community) learning model. WiredAcademic.

Godwin-Jones, R. (2014). Global reach and local practice: The promise of MOOCS. Language Learning \& Technology, 18(3), 5-15.

Grünewald, F., Meinel, C., Totschnig, M., \& Willems, C. (2013). Designing MOOCs for the support of multiple learning styles. In D. Hernández-Leo, T. Ley, R. Klamma, \& A. Harrer (Eds.), Scaling up learning for sustained impact (pp. 371-382). Berlin, Heidelberg: Springer Berlin Heidelberg.

Gunawardena, C. N. (2014a). Online identities and interaction. In I. Jung \& C. N. Gunawardena, (Eds.), Culture and online learning (pp. 34-44). Sterling, VA: Stylus.

Gunawardena, C. N. (2014b). Supporting diverse online learners. In I. Jung \& C. N. Gunawardena (Eds.), Culture and online learning (pp. 79-90). Sterling, VA: Stylus.

Gunawardena, C. N., \& Jayatilleke, B. G. (2014). Facilitating online learning and cross-cultural e-mentoring. In I. Jung \& C. N. Gunawardena (Eds.), Culture and online learning (pp. 67-78). Sterling, VA: Stylus.

Hulme, M. (2010). Problems with making and governing global kinds of knowledge. Global Environmental Change, 20, 558-564.

Hou, H.-T., Wang, S.-M., Lin, P.-C., \& Chang, K.-E. (2015). Exploring the learner's knowledge construction and cognitive patterns of different asynchronous platforms: Comparison of an online discussion forum and Facebook. Innovations in Education and Teaching International, 52(6), 610-620. doi:10.1080/14703297.2013.847381

Jeong, H., Cress, U., Moskaliuk, J., \& Kimmerle, J. (2017). Joint interactions in large online knowledge communities: The A3C framework. International Journal of ComputerSupported Collaborative Learning, 12(2), 133-151. doi:10.1007/s11412-017-9256-8

Jung, I. (2014). Cultural influences on online learning. In I. Jung \& C. N. Gunawardena (Eds.), Culture and online learning (pp. 15-24). Sterling, VA: Stylus.

Jung, I., \& Gunawardena, C. N. (Eds.). (2014). Culture and online learning: Global perspectives and research. Sterling, VA: Stylus.

Ke, F. (2010). Examining online teaching, cognitive, and social presence for adult students. Computers \& Education, 55(2), 808-820.

doi:http://dx.doi.org/10.1016/j.compedu.2010.03.013

Kellogg, S., Booth, S., \& Oliver, K. (2014). A social network perspective on peer supported learning in MOOCs for educators. The International Review of Research in Open and Distributed Learning, 15(5), 163-289. 
Kizilcec, R. F., Saltarelli, A. J., Reich, J., \& Cohen, G. L. (2017). Closing global achievement gaps in MOOCs: Brief interventions address social identity threat at scale. Science, 355(6322), 251-252. doi:10.1126/science.aag2063

Koller, D. (2012). What we're learning from online education. Retrieved from https://www.ted.com/talks/daphne koller_what we re learning from online education/ transcript?language $=\mathrm{en}$

Krasny, M. E., \& Dillon, J. (2013). Trading zones in environmental education: Creating transdisciplinary dialogue. New York City, NY: Peter-Lang.

Krasny, M. E., \& Snyder, K. (Eds.). (2016). Civic ecology: Stories about love of life, love of place. Ithaca, NY: Civic Ecology Lab. Retrieved from https://civeco.files.wordpress.com/2015/12/krasny_snyder_mooc_stories_2016.pdf

Kulkarni, C., Cambre, J., Kotturi, Y., Bernstein, M. S., \& Klemmer, S. R. (2015). Talkabout: Making distance matter with small groups in massive classes. Paper presented the Proceedings of the 18th ACM Conference on Computer Supported Cooperative Work \& Social Computing, Vancouver, BC, Canada.

Laurillard, D. (2016). The educational problem that MOOCs could solve: Professional development for teachers of disadvantaged students. Research in Learning Technology, 24(1), 29369. doi:10.3402/rlt.v24.29369

Li, N., Verma, H., Skevi, A., Zufferey, G., Blom, J., \& Dillenbourg, P. (2014). Watching MOOCs together: Investigating co-located MOOC study groups. Distance Education, 35(2), 217-233. doi:10.1080/01587919.2014.917708

Li, Y. (2016). Professional networks and practice change in environmental education (Unpublished dissertation). Cornell University, Ithaca, NY.

Li, Y., Krasny, M. E., \& Russ, A. (2014). Interactive learning in an online urban environmental education course. Environmental Education Research, 22(1), 111-128.

Liu, C.-J., \& Yang, S. C. (2014). Using the Community of Inquiry model to investigate students' knowledge construction in asynchronous online discussions. Journal of Educational Computing Research, 51(3), 327-354. doi:10.2190/EC.51.3.d

Liyanagunawardena, T., \& Adams, A. (2014). The impact and reach of MOOCs: A developing country perspective. eLearning Papers Special Edition, 38-46.

Macià, M., \& García, I. (2016). Informal online communities and networks as a source of teacher professional development: A review. Teaching and Teacher Education, 55, 291-307. doi:http://dx.doi.org/10.1016/j.tate.2016.01.021

Macià, M., \& Garcia, I. (2017). Properties of teacher networks in Twitter: Are they related to community-based peer production? International Review of Research in Open and Distance Learning, 18(1), 111-140.

Margaryan, A., Bianco, M., \& Littlejohn, A. (2015). Instructional quality of Massive Open Online Courses (MOOCs). Computers \& Education, 80, 77-83. doi:http://dx.doi.org/10.1016/j.compedu.2014.08.005 
Meinel, C., \& Schweiger, S. (2016). A virtual social learning community-constitutive element of MOOCs. Education Sciences, 6(22). doi:10.3390/educsci6030022

Nkuyubwatsi, B. (2014). Cultural translation in Massive Open Online Courses (MOOCs). eLearning Papers, 37.

Reed, M. S., Evely, A. C., Cundill, G., Fazey, I., Glass, J., Laing, A., . . Stringer, L. C. (2010). What is social learning? Ecology and Society, 15(4).

Russ, A. (2015). Urban environmental education. Ithaca, NY: Cornell University Civic Ecology Lab.

Saldaña, J. (2013). The coding manual for qualitative researchers (2nd ed.). London UK: Sage.

Salmon, G., Ross, B., Pechenkina, E., \& Chase, A. (2015). The space for social media in structured online learning. Research in Learning Technology, 23(28507).

Stewart, B. (2013). Massiveness + openness = new literacies of participation? Journal of Online Learning and Teaching, 9(2), 228.

Tajfel, H., \& Turner, J. C. (1986). The social identity theory of intergroup behavior. In S. Worchel \& L. W. Austin (Eds.), Psychology of intergroup relations (pp. 7-24). Chicago, IL: Nelson Hall.

Wals, A. E. J. (2007). Social learning towards a sustainable world: Principles, perspectives, and praxis. Wageningen, The Netherlands: Wageningen Academic Publishers.

Wals, A. E. J., van der Hoeven, N., \& Blanken, H. (2009). The acoustics of social learning: Designing learning processes that contribute to a more sustainable world. Wageningen, The Netherlands: Wageningen Academic Publishers.

Yuan, J., \& Kim, C. (2014). Guidelines for facilitating the development of learning communities in online courses. Journal of Computer Assisted Learning, 30(3), 220-232. doi:10.1111/jcal.12042

Zhang, J., Scardamalia, M., Reeve, R., \& Messina, R. (2009). Designs for collective cognitive responsibility in knowledge-building communities. Journal of the Learning Sciences, 18(1), 7-44. doi:10.1080/10508400802581676 
Small Groups in a Social Learning MOOC (sIMOOC): Strategies for Fostering Learning and Knowledge Creation 